Method A study was carried out on Asaba-Agbor road and Onitsha-Mgbidi roads of about $115 \mathrm{~km}$. 20 checkpoints were investigated and 40 drivers were interviewed. Questionnaires were distributed to 100 road users.

Analysis $90 \%$ of respondents confirmed that road blockage were a major contributor to road crashes. $80 \%$ of drivers interviewed said the road blockage served as points for illegal collection of bribes by many compromising and corrupt enforcement officers. No standardised road furniture was used to identify checkpoints. All sorts of dangerous materials were used to block roads ranging from huge stones, thick woods to items of great threat to road use. 15 abandoned damaged vehicles were noted near the checkpoints. Information could not be obtained from the police officers on the cause of such road crashes but $62 \%$ of respondents interviewed attributed such incidents to road blockage at checkpoints.

Conclusion Road blockage contributes to rising road fatalities and injuries on Nigerian roads. Proper and standardised checkpoints are very necessary and the Nigerian legislature should make laws that would stipulate stiff penalties for defaulting law enforcement agents.

\title{
0594 ADDRESSING ILLEGAL ROAD BLOCKAGE BY LAW ENFORCEMENT AGENTS AND ITS ATTENDANT ROAD DEATHS
}

A Maxwell*, E Anisha, C Ojugbana, C Unoka Correspondence: PATVORA Initiative, 24 Ojugbana Drive, Ezenei Avenue Box 505, Asaba, Delta State Nigeria www.patvora. org, 23456, Nigeria

10.1136/ip.2010.029215.594

Present position Nigerian roads are well known to have claimed so many preventable lives due to road blockage mounted by law enforcement officers especially policemen. Despite the existing ban on checkpoints on most highways, illegal road blockage remains a common feature.

Aim The study investigates existing checkpoints on Nigeria highways to determine measures for reducing associated deaths and injuries. 